\title{
Corrosion Behavior of API 5L X65 Carbon Steel Under Supercritical and Liquid Carbon Dioxide Phases in the Presence of Water and Sulfur Dioxide
}

\author{
F. Farelas, ${ }^{\ddagger *}{ }^{*}$ Y.S. Choi, ${ }^{\star}$ and S. Nešić ${ }^{*}$
}

\begin{abstract}
Depending on the capture process, liquid or supercritical carbon dioxide $\left(\mathrm{CO}_{2}\right)$ can contain impurities like water $\left(\mathrm{H}_{2} \mathrm{O}\right)$ and sulfur dioxide $\left(\mathrm{SO}_{2}\right)$, increasing the likelihood of corrosion of carbon steel pipelines even if there is no free water in the system. To understand the corrosion risk for such pipelines, the present study focused on the effects of $\mathrm{CO}_{2}$ phase change, water, and $\mathrm{SO}_{2}$. Different $\mathrm{CO}_{2}$ phases (liquid and supercritical) and concentrations of $\mathrm{SO}_{2}(<1 \%)$ were simulated in an autoclave-based study. The corrosion rate of steel samples was determined with weight-loss (WL) measurements. The surface morphology and the composition of the corrosion product layers were analyzed using surface analytical techniques (scanning electron microscopy [SEM], energy-dispersive spectroscopy [EDS], and infinite focus microscopy [IFM]). Results showed that the corrosion rate decreased with decreasing $\mathrm{SO}_{2}$ content in the supercritical $\mathrm{CO}_{2}$ phase containing 650 ppmv of water with no localized attack. In contrast, in high-pressure liquid $\mathrm{CO}_{2}$, significant localized corrosion was observed.
\end{abstract}

KEY WORDS: carbon capture and storage, carbon dioxide corrosion, carbon dioxide transport, corrosion, liquid and supercritical carbon dioxide, sulfur dioxide

\section{INTRODUCTION}

It has been acknowledged that green house gas (GHG) emissions caused by human activities, such as car-

Submitted for publication: May 15, 2012. Revised and accepted: August 3, 2012. Preprint available online: October 17, 2012, http://dx.doi.org/10.5006/0739.

‡ Corresponding author. E-mail: farelas@ohio.edu.

* Institute for Corrosion and Multiphase Technology, Department of Chemical and Biomolecular Engineering, Ohio University, Athens, $\mathrm{OH} 45701$. bon dioxide $\left(\mathrm{CO}_{2}\right)$, methane $\left(\mathrm{CH}_{4}\right)$, and nitrous oxide $\left(\mathrm{N}_{2} \mathrm{O}\right)$, are one of the principal reasons for climate change. Among them, $\mathrm{CO}_{2}$ has been given much attention because $\mathrm{CO}_{2}$ emissions from fossil fuel combustion have been increasing at an average annual rate of $0.4 \%$ from 1990 to 2009 , representing $79 \%$ of the total emissions in 2009. ${ }^{1}$ Coal, natural gas, and oil-fired power plants are together the largest $\mathrm{CO}_{2}$ emitter. A way to reduce $\mathrm{CO}_{2}$ emissions to the atmosphere is through carbon capture and storage (CCS). This method consists of capturing $\mathrm{CO}_{2}$ at the source, transporting it to a suitable storage site, and sequestering it in geological formations such as oil and gas reservoirs, deep saline aquifers, and coal beds. ${ }^{2}$

One of the forms for transporting $\mathrm{CO}_{2}$ from the point sources to storage sites is through pipelines manufactured from high-strength steels X65 and $\mathrm{X70}$, which has been established as the most economical approaches of transporting $\mathrm{CO}_{2}$ to sequestration sites. ${ }^{3-4}$ Before the $\mathrm{CO}_{2}$ is injected in the pipeline, it is dried sufficiently with the purpose of avoiding the presence of free water and then compressed to a dense state (liquid or supercritical phase). From an economical point of view, large volumes of $\mathrm{CO}_{2}$ can be transported in the dense state because it has a liquidlike density but behaves as a gas, allowing the use of smaller pipeline diameters and larger flow rates. ${ }^{5}$

Some studies have reported that dried supercritical $\mathrm{CO}_{2}$ is not corrosive. ${ }^{6-8}$ This noncorrosive property of dry supercritical $\mathrm{CO}_{2}$ can be ascribed to its low conductivity $\left(3 \times 10^{-5} \mathrm{~S} / \mathrm{m}\right)$, two orders of magnitude lower than supercritical $\mathrm{CO}_{2}$ saturated with water $\left(7 \times 10^{-3} \mathrm{~S} / \mathrm{m}\right) .{ }^{6}$ However, depending on the captured 
process, $\mathrm{CO}_{2}$ could contain impurities like water, oxygen, and sulfur dioxide $\left(\mathrm{SO}_{2}\right)$, among others. Such impurities could be the source of corrosion problems for the carbon steel pipelines..$^{3,7,9-11}$

Several researches have been conducted on corrosion of materials in liquid and supercritical $\mathrm{CO}_{2}$ contaminated by water, $\mathrm{O}_{2}$, and $\mathrm{SO}_{2}$. Recently, it was claimed that water mist saturated with supercritical $\mathrm{CO}_{2}$ was corrosive for C-steels and responsible of localized attack when water mist droplets, saturated with supercritical $\mathrm{CO}_{2}$, touched the carbon steel surface. ${ }^{9}$ In addition, no corrosion was observed for $13 \mathrm{Cr}$ or $\mathrm{Cr}-\mathrm{Ni}$ steels even up to $130^{\circ} \mathrm{C}$.

Corrosion experiments conducted on X70 steel and iron in water-saturated supercritical $\mathrm{CO}_{2}$ mixed with $\mathrm{SO}_{2}$ showed that the corrosion rate of X70 steel increased as the $\mathrm{SO}_{2}$ concentration increased. ${ }^{3}$ The corrosion products found by $\mathrm{x}$-ray diffraction (XRD) and $\mathrm{x}$-ray photoelectron spectroscopy (XPS) were mainly hydrates of iron(II) sulfate $\left(\mathrm{FeSO}_{4}\right)$ and iron sulfite $\left(\mathrm{FeSO}_{3}\right)$. It was stated that the presence of $\mathrm{SO}_{2}$ intensifies the corrosiveness of the water-saturated supercritical $\mathrm{CO}_{2}$, and the corrosion caused by $\mathrm{SO}_{2}$ is much more intense than that caused by $\mathrm{CO}_{2}$.

Dugstad, et al., ${ }^{9}$ showed that dense phase (liquid) $\mathrm{CO}_{2}$ with water content significantly lower than the solubility limit is non-corrosive. However, corrosion can take place in dense phase $\mathrm{CO}_{2}$ at a water content of 200 ppmv (wt) when $\mathrm{SO}_{2}$ and $\mathrm{O}_{2}$ are present. In contrast, corrosion rates of approximately $1 \mathrm{~mm} / \mathrm{y}$ have been reported in pure $\mathrm{CO}_{2}$ with just 100 ppmv of water. $^{10}$

Choi and Nešić ${ }^{11}$ studied the effect of water content on the corrosion of carbon steel in supercritical $\mathrm{CO}_{2} / \mathrm{O}_{2}$ phase. It was found that as long as the water content is kept below its solubility limit in $\mathrm{CO}_{2}\left(3,300 \mathrm{ppmv}\right.$ at $8 \mathrm{MPa}$ and $\left.50^{\circ} \mathrm{C}\right)$, no significant attack will take place. However, it was also reported that the addition of $1 \% \mathrm{SO}_{2}$ in the gas phase dramatically increased the corrosion rate of carbon steel to $3.5 \mathrm{~mm} / \mathrm{y}$ with only $650 \mathrm{ppmv}$ of water, concentration, which is significantly below the solubility limit in $\mathrm{CO}_{2}$ and the current unofficial industry standard: the so-called Kinder Morgan specification for transporting $\mathrm{CO}_{2}$ in pipelines. ${ }^{12}$

Considering the real situations for $\mathrm{CO}_{2}$ transport pipelines, effects of $\mathrm{CO}_{2}$ phase and $\mathrm{SO}_{2}$ concentration should be qualified further to establish a clear understanding of the corrosion risk for such pipelines. Therefore, the goal of the present study was to study the corrosion behavior of carbon steel exposed to liquid and supercritical $\mathrm{CO}_{2}$ with impurities such as water (below the solubility limit: $650 \mathrm{ppmv}$ ) and $\mathrm{SO}_{2}$ (small amounts: <1\%). To achieve these goals,

\footnotetext{
(1) UNS numbers are listed in Metals and Alloys in the Unified Numbering System, published by the Society of Automotive Engineers (SAE International) and cosponsored by ASTM International.

(2) American Petroleum Institute (API), 1220 L St. NW, Washington, DC 20005.
}

corrosion tests were performed in an autoclave. Corrosion rate of samples were determined by weight-loss measurements. The morphology and compositions of corrosion products were analyzed using scanning electron microscopy (SEM) and energy-dispersive $\mathrm{x}$-ray spectroscopy (EDS). To measure the pit depth when localized corrosion was observed, infinite focus microscopy (IFM) was used.

\section{EXPERIMENTAL PROCEDURES}

Corrosion tests were performed in a $1,000 \mathrm{~mL}$ Type 316 (UNS S31600) ${ }^{(1)}$ stainless steel autoclave. A schematic drawing of the pressurized system is shown in Figure 1. Test samples were machined from API $5 \mathrm{~L}^{(2)} \mathrm{X} 65$ pipeline steel with a $10.7 \mathrm{~cm}^{2}$ exposed area. At one end of the samples, a $1 \mathrm{~mm}$ diameter hole was made to hang them inside the autoclave. Table 1 shows the chemical composition of the pipeline steel used for the corrosion tests.

Before each experiment, the samples were ground with 600 grit silicon carbide ( $\mathrm{SiC}$ ) paper, cleaned with isopropyl alcohol $\left(\mathrm{C}_{3} \mathrm{H}_{8} \mathrm{O}\right)$ in an ultrasonic bath, dried, and weighed using a balance with a precision of $0.1 \mathrm{mg}$. Two samples were placed inside the autoclave and 650 ppmv of deionized (DI) water was added at the bottom of the system. The amount of water was chosen taking into account the drying requirement for $\mathrm{CO}_{2}$ pipelines used for enhanced oil recovery (EOR) in the United States, which is 650 ppmv maximum. ${ }^{12}$ Once sealed, the autoclave temperature was adjusted. Then, a technical-grade $\mathrm{SO}_{2}$ was injected directly into the autoclave to the desired pressure. Finally, highpressure $\mathrm{CO}_{2}$ was added to the autoclave with a gas booster pump to the desired working pressure. Details of the experimental matrix are given in Table 2 .

Figure 2 shows the phase diagram for pure $\mathrm{CO}_{2}$ and in the presence of different $\mathrm{SO}_{2}$ amounts. Values for the critical points for pure $\mathrm{CO}_{2}$ and $\mathrm{CO}_{2} / \mathrm{SO}_{2}$ mixtures are reported in Table $2 .{ }^{13}$ At pressures and temperatures above the critical point, the $\mathrm{CO}_{2}$ is present in a supercritical state. At pressures above and temperatures below the critical point, the $\mathrm{CO}_{2}$ exists as a liquid. Usually, the presence of impurities causes the formation of a two-phase gas-liquid region; ${ }^{14}$ however, as shown in Figure 2 and Table 3, the presence of $\mathrm{SO}_{2}$ does not have a big influence on the formation of a two-phase region nor on the critical points.

The weight-loss method was used to calculate the average corrosion rate for two samples, which were exposed simultaneously to the aggressive environment for $24 \mathrm{~h}$. After surface analysis, the samples were cleaned using the Clarke's solution, ${ }^{15}$ rinsed in DI water, dried, and weighed. Equation (1) was used to calculate the average corrosion rate:

$\mathrm{CR}=\frac{8.76 \times 10^{4}(\mathrm{~mm} \cdot \text { hour } / \mathrm{cm} \cdot \text { year }) \times \text { weight loss }(\mathrm{g})}{\left.\text { area }\left(\mathrm{cm}^{2}\right) \times \text { density }\left(\mathrm{g} / \mathrm{cm}^{3}\right) \times \text { time (hour }\right)}$ 


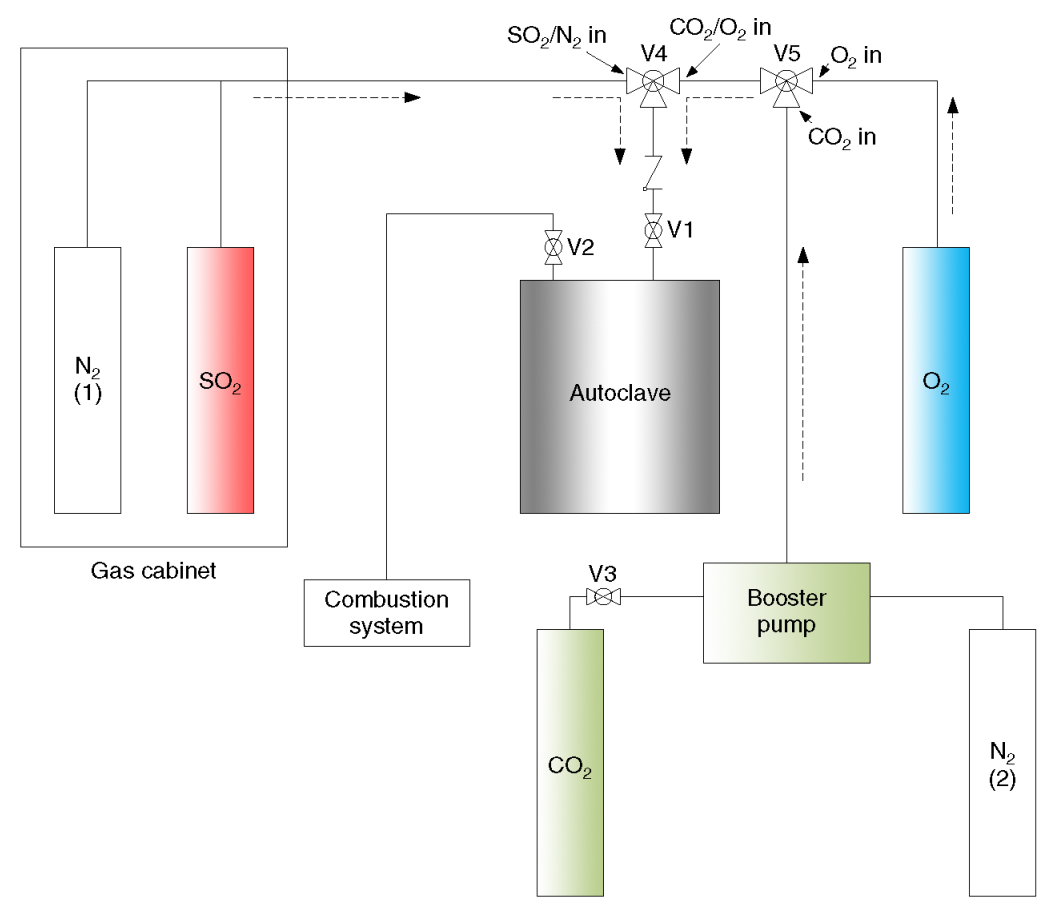

FIGURE 1. Schematic drawing of the $\mathrm{CO}_{2} / \mathrm{SO}_{2}$ pressurized system used for the corrosion tests.

TABLE 1

Elemental Analysis for the API 5 L X65 Carbon Steel (wt\%)

\begin{tabular}{ccccccccccc}
\hline $\mathbf{C}$ & $\mathbf{M n}$ & $\mathbf{S i}$ & $\mathbf{P}$ & $\mathbf{S}$ & $\mathbf{C r}$ & $\mathbf{C u}$ & $\mathbf{N i}$ & $\mathbf{M o}$ & $\mathbf{A l}$ & $\mathbf{F e}$ \\
\hline 0.065 & 1.54 & 0.25 & 0.013 & 0.001 & 0.05 & 0.04 & 0.04 & 0.007 & 0.041 & Balance \\
\hline
\end{tabular}

TABLE 2

Experimental Matrix for the Corrosion Tests

\begin{tabular}{ll}
\hline \multicolumn{1}{c}{ Parameter } & \multicolumn{1}{c}{ Description } \\
\hline Material & API $5 \mathrm{~L} \mathrm{X65}$ \\
Solution & DI water $(650 \mathrm{ppm})$ \\
Temperature $\left({ }^{\circ} \mathrm{C}\right)$ & 25,50 \\
$\mathrm{CO}_{2}$ partial pressure $(\mathrm{MPa})$ & 8 \\
$\mathrm{SO}_{2}$ partial pressure (bar) & $0.08,0.04(0.1$ and $0.05 \%$ in \\
& gas phase) \\
$\mathrm{CO}_{2}$ phase Liquid & Density: $776.6 \mathrm{~kg} / \mathrm{cm}^{3}$, \\
& viscosity: $20.4 \mu \mathrm{Pa}-\mathrm{s}$ \\
\multicolumn{1}{c}{ Supercritical } & Density: $219.1 \mathrm{~kg} / \mathrm{cm}^{3}$, \\
& viscosity: $20.4 \mu \mathrm{Pa}-\mathrm{s}$ \\
Test methods & WL, SEM, EDS, IFM \\
Test period $(\mathrm{h})$ & 24 \\
\hline
\end{tabular}

The morphology and compositions of corrosion products were analyzed using SEM and EDS. To measure the pit depths when localized corrosion was observed, IFM was used.

\section{RESULTS AND DISCUSSION}

\section{Corrosion Tests in Supercritical $\mathrm{CO}_{2}$ with Impurities}

In the absence of $\mathrm{SO}_{2}$ and when the water is kept below its solubility limit in supercritical $\mathrm{CO}_{2}$, no cor-

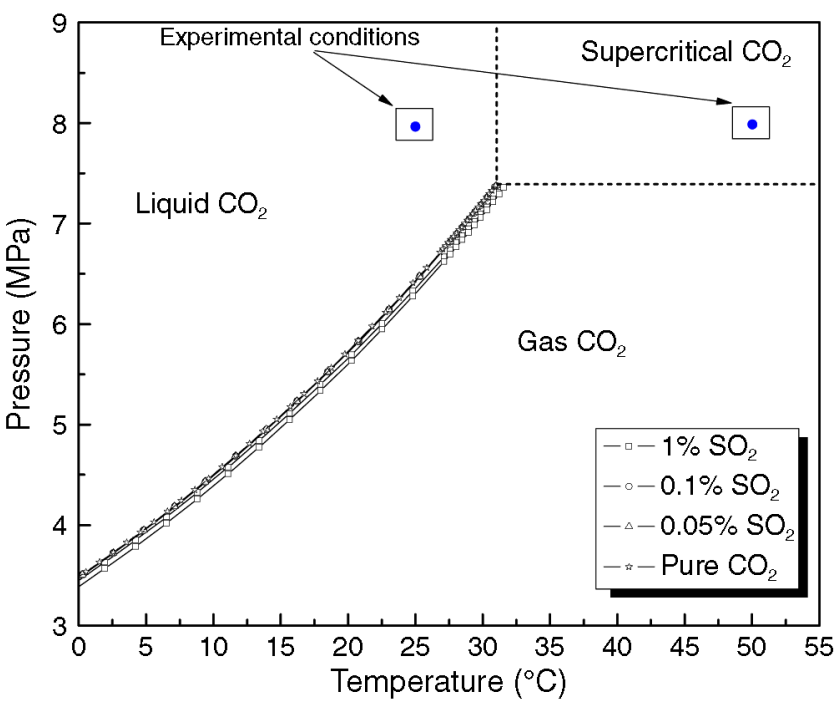

FIGURE 2. Phase diagram for $\mathrm{CO}_{2}$ with different $\mathrm{SO}_{2}$ amounts. ${ }^{13}$

rosion has been observed. ${ }^{11}$ However, the presence of $\mathrm{SO}_{2}$ in the system can increase the corrosion rate. The effect of $\mathrm{SO}_{2}$ concentration on the corrosion rate of an API 5L X65 steel exposed to supercritical $\mathrm{CO}_{2} / \mathrm{SO}_{2}$ phase is shown in Figure 3. Corrosion rate at $1 \% \mathrm{SO}_{2}$ $(0.08 \mathrm{MPa})$ was reported in a previous study and it is 
TABLE 3

Critical Point Conditions for Pure $\mathrm{CO}_{2}$ and in the Presence of $\mathrm{SO}_{2}{ }^{13}$

\begin{tabular}{lcc}
\hline \multicolumn{1}{c}{ Component } & $\begin{array}{c}\text { Critical } \\
\text { Pressure } \\
(\mathbf{M P a})\end{array}$ & $\begin{array}{c}\text { Critical } \\
\text { Temperature } \\
\left({ }^{\circ} \mathbf{C}\right)\end{array}$ \\
\hline $\mathrm{CO}_{2}$ & 7.37 & 30.97 \\
$\mathrm{CO}_{2}+0.05 \% \mathrm{SO}_{2}$ & 7.37 & 31.00 \\
$\mathrm{CO}_{2}+0.1 \% \mathrm{SO}_{2}$ & 7.37 & 31.03 \\
$\mathrm{CO}_{2}+1.0 \% \mathrm{SO}_{2}$ & 7.35 & 31.55 \\
\hline
\end{tabular}

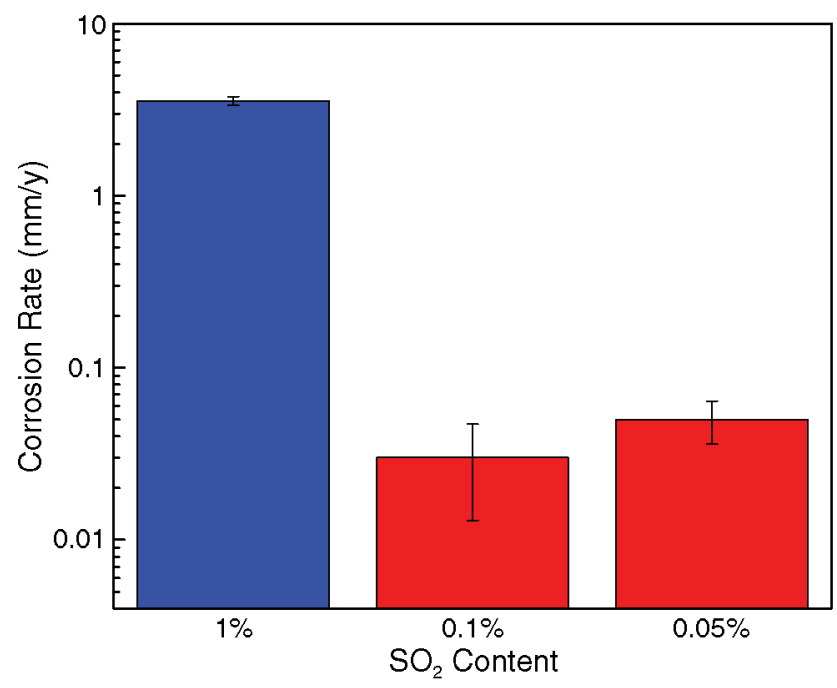

FIGURE 3. Effect of $\mathrm{SO}_{2}$ concentration on the corrosion rate of carbon steel exposed in the supercritical $\mathrm{CO}_{2}$ phase for $24 \mathrm{~h}$, at a $\mathrm{CO}_{2}$ partial pressure of $8 \mathrm{MPa}, 50^{\circ} \mathrm{C}$, with 650 ppmv water.

reproduced here as a reference point. ${ }^{11}$ It can be observed that the corrosion rate decreased sharply when $\mathrm{SO}_{2}$ concentration was reduced from $1 \%$ $(0.08 \mathrm{MPa})$ to $0.1 \%(0.008 \mathrm{MPa})$. A further decrease in $\mathrm{SO}_{2}$ content did not show any effect in the corrosion rate and no significant difference between $0.1 \%$ and $0.05 \%(0.004 \mathrm{MPa})$ was observed.

Figure 4 shows the surface morphology of the corroded weight-loss (WL) coupons at different $\mathrm{SO}_{2}$ concentrations exposed for $24 \mathrm{~h}$ in the supercritical $\mathrm{CO}_{2} / \mathrm{SO}_{2}$ phase with 650 ppmv of water. Figure $4(\mathrm{a})$ was already reported in a previous publication and it is shown here as a comparison point for the other experimental conditions. Figure 4(a) shows a surface covered by a dendritic corrosion product. According to Choi and Nešić, ${ }^{11}$ the corrosion product was a mixture of hydrated $\mathrm{FeSO}_{3}$ and $\mathrm{FeSO}_{4}$. The formation of $\mathrm{FeSO}_{3}$ and $\mathrm{FeSO}_{4}$ in the presence of $\mathrm{SO}_{2}$ and water can be explained by the following reactions: ${ }^{16}$

$$
\begin{gathered}
\mathrm{SO}_{2}+\mathrm{H}_{2} \mathrm{O} \rightarrow \mathrm{SO}_{3}^{2-}+2 \mathrm{H}^{+} \\
\mathrm{Fe}^{2+}+\mathrm{SO}_{3}^{2-} \rightarrow \mathrm{FeSO}_{3} \\
\mathrm{SO}_{3}^{2-}+\mathrm{H}_{2} \mathrm{O} \rightarrow \mathrm{SO}_{4}^{2-}+2 \mathrm{H}^{+}+2 \mathrm{e}^{-}
\end{gathered}
$$

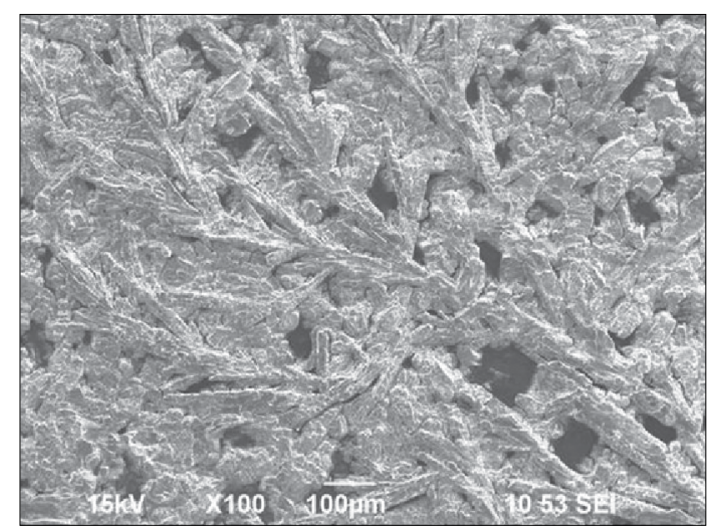

(a)

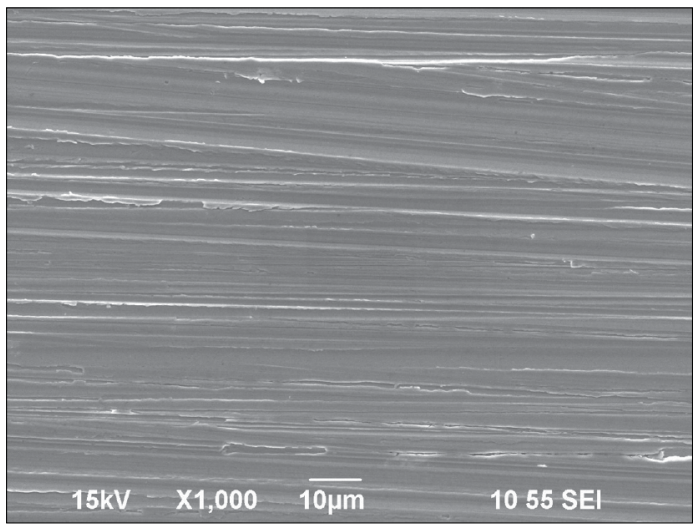

(b)

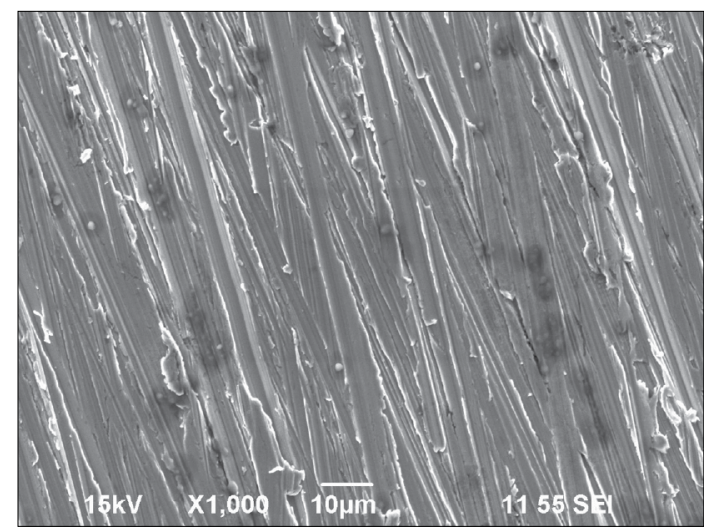

(c)

FIGURE 4. SEM pictures of WL coupon surfaces after being exposed for $24 \mathrm{~h}$ in supercritical $\mathrm{CO}_{2}$ phase, at a $\mathrm{CO}_{2}$ partial pressure of $8 \mathrm{MPa}, 50^{\circ} \mathrm{C}$, with $650 \mathrm{ppmv}$ water: (a) $1.0 \% \mathrm{SO}_{2}$, (b) $0.1 \% \mathrm{SO}_{2}$, (c) $0.05 \% \mathrm{SO}_{2}$.

$$
\mathrm{Fe}^{2+}+\mathrm{SO}_{4}^{2-} \rightarrow \mathrm{FeSO}_{4}
$$

The surface of the samples for $0.1 \%$ and $0.05 \%$ $\mathrm{SO}_{2}$ are shown in Figures 4(b) and 3(c), respectively. No visible signs of corrosion were observed for both conditions even at high magnification, i.e., the steel surfaces showed polishing marks and an absence of any corrosion products, which is in qualitative agreement with the low corrosion rate obtained by WL. 


\section{Corrosion Tests in Liquid $\mathrm{CO}_{2}$ with Impurities}

Tests in supercritical $\mathrm{CO}_{2} / \mathrm{SO}_{2}$ phase described above revealed that corrosion of carbon steel can take place even if the concentration of water (650 ppmv) is below its solubility limit. However, corrosion rate was negligible when $\mathrm{SO}_{2}$ concentration was below $0.1 \%$. On the other hand, during the transport of $\mathrm{CO}_{2}$ in pipelines, $\mathrm{CO}_{2}$ can be either in the liquid or supercritical phase. Therefore, it is also important to study the behavior of carbon steels when exposed to liquid $\mathrm{CO}_{2}$ with impurities such as water and $\mathrm{SO}_{2}$.

Figure 5 shows the corrosion rates of carbon steel exposed to a liquid $\mathrm{CO}_{2}$ phase $\left(8 \mathrm{MPa} \mathrm{CO}_{2}, 25^{\circ} \mathrm{C}\right)$ with different $\mathrm{SO}_{2}$ contents. Although the general corrosion rates were low in the liquid $\mathrm{CO}_{2}$ phase with $0.1 \% \mathrm{SO}_{2}$ $(\approx 0.1 \mathrm{~mm} / \mathrm{y})$, the corrosion rates measured in the liquid $\mathrm{CO}_{2}$ phase showed higher values than were measured in the supercritical $\mathrm{CO}_{2}$ phase $(\approx 0.03 \mathrm{~mm} / \mathrm{y})$. However, in liquid $\mathrm{CO}_{2}$ with only $0.05 \% \mathrm{SO}_{2}$, there was no measurable specimen weight change (less than $0.1 \mathrm{mg} / \mathrm{cm}^{2}$ ) after $24 \mathrm{~h}$, indicating an insignificant corrosion rate.

Observation of the corrosion surface of the sample exposed to the liquid $\mathrm{CO}_{2} / \mathrm{SO}_{2}$ phase with $0.1 \%$ $\mathrm{SO}_{2}$ revealed the presence of heterogeneous, globular corrosion products in an otherwise uniformly cracked layer (Figure 6). According to the chemical analysis performed by EDS (Table 4), the globular corrosion product consisted mainly of iron, oxygen, and sulfur. The cracked layer indicated the same chemical elements by the EDS analysis. In a previous research

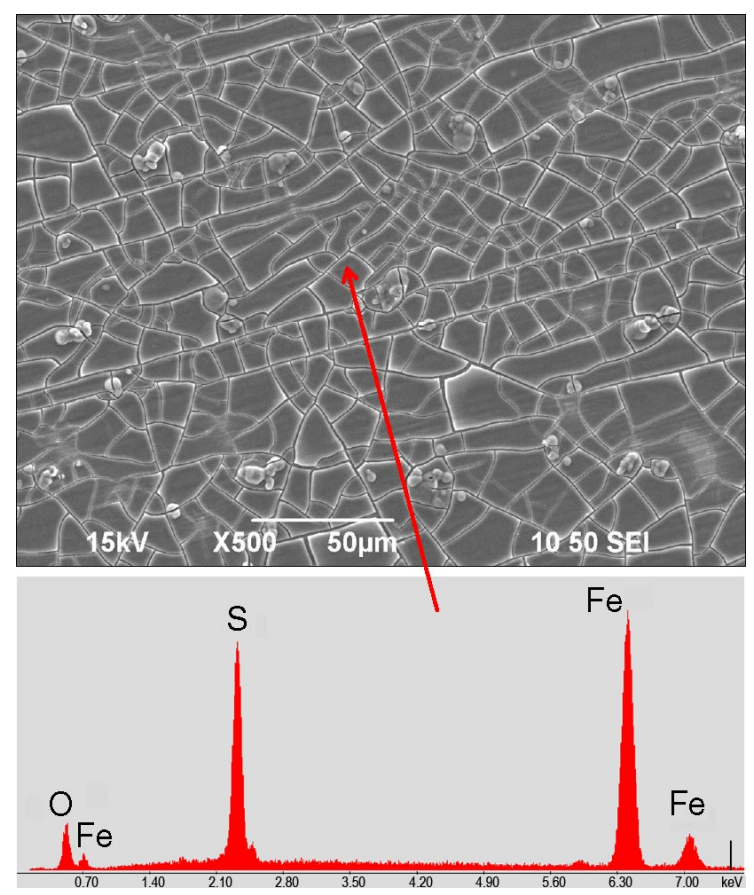

(a)

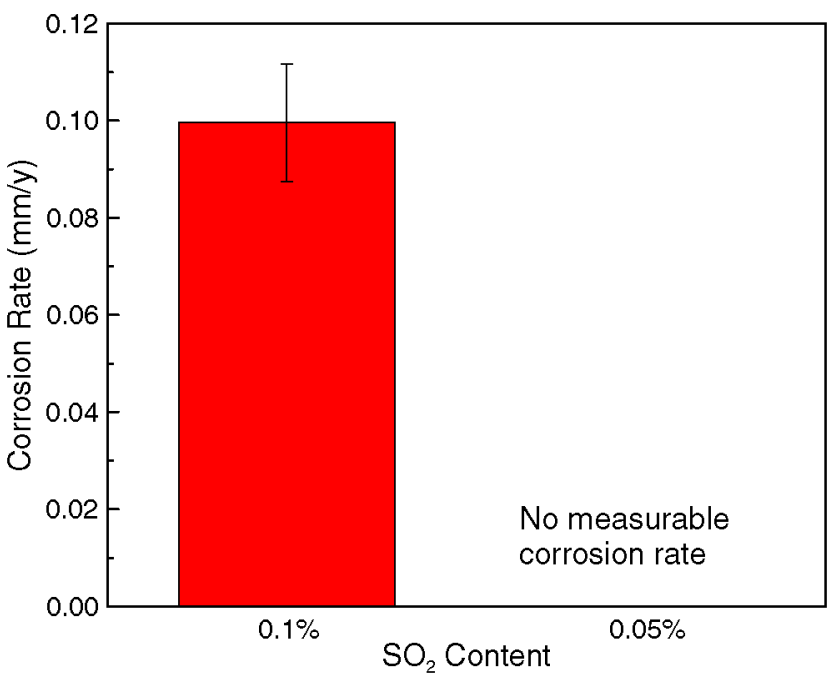

FIGURE 5. Effect of $\mathrm{SO}_{2}$ content on the corrosion rate of carbon steel exposed in the liquid $\mathrm{CO}_{2}$ phase for $24 \mathrm{~h}$, at a $\mathrm{CO}_{2}$ partial pressure of $8 \mathrm{MPa}, 25^{\circ} \mathrm{C}$, with 650 ppmv water.

TABLE 4

Results from the Energy-Dispersive Spectroscopy Chemical Analysis

\begin{tabular}{|c|c|c|c|c|c|c|}
\hline \multirow[b]{2}{*}{ Element } & \multicolumn{2}{|c|}{ Figure 6(a) } & \multicolumn{2}{|c|}{ Figure 6(b) } & \multicolumn{2}{|c|}{ Figure 7} \\
\hline & wt $\%$ & at $\%$ & wt $\%$ & at $\%$ & wt $\%$ & at $\%$ \\
\hline 0 & 7.77 & 20.41 & 8.85 & 21.13 & 12.00 & 29.46 \\
\hline$S$ & 18.31 & 23.98 & 32.64 & 38.87 & 1.35 & 1.65 \\
\hline $\mathrm{Fe}$ & 73.92 & 55.61 & 58.51 & 40.00 & 83.56 & 58.78 \\
\hline C & & & & & 3.09 & 10.11 \\
\hline
\end{tabular}

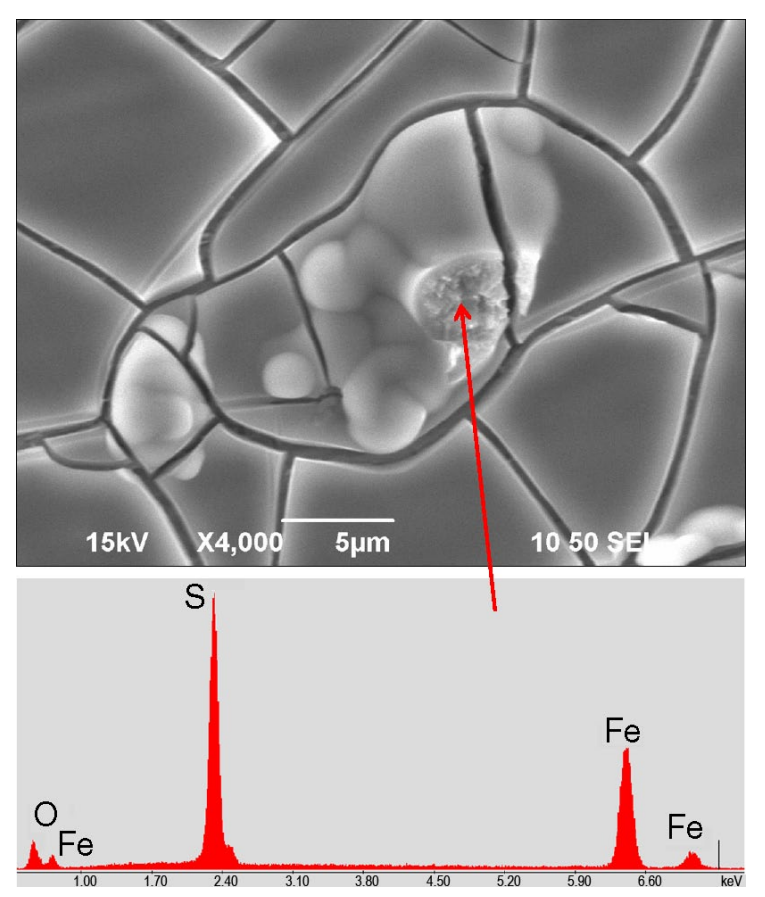

(b)

FIGURE 6. SEM images at different magnifications and EDS analysis of the corresponding area of the corroded surface of the coupon exposed to the liquid $\mathrm{CO}_{2}$ for $24 \mathrm{~h}$, at a $\mathrm{CO}_{2}$ partial pressure of $8 \mathrm{MPa}, 25^{\circ} \mathrm{C}$, with $0.1 \% \mathrm{SO}_{2}$. 


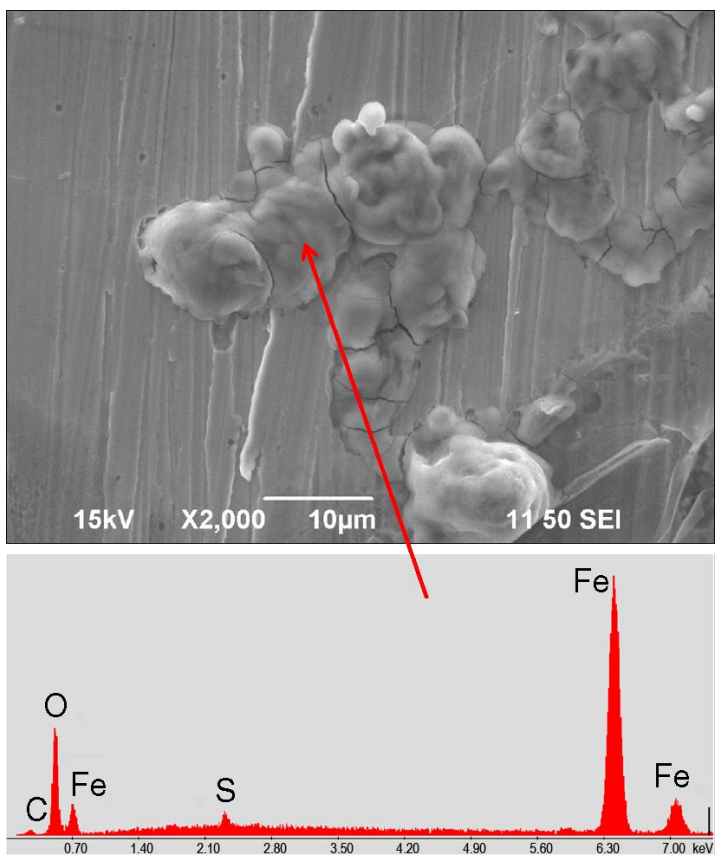

FIGURE 7. SEM image and EDS spectra of the corroded surface of the sample exposed to the liquid $\mathrm{CO}_{2}$ for $24 \mathrm{~h}$, at a $\mathrm{CO}_{2}$ partial pressure of $8 \mathrm{MPa}, 25^{\circ} \mathrm{C}$, with $0.05 \% \mathrm{SO}_{2}$.

study, this corrosion product was reported to be hydrated $\mathrm{FeSO}_{3}$ and $\mathrm{FeSO}_{4} \cdot{ }^{11}$

Figure 7 shows the corroded surface and the EDS analysis of the metal sample after being exposed to a liquid $\mathrm{CO}_{2}$ phase with $0.05 \% \mathrm{SO}_{2}$. Although no significant corrosion rate was measured, a globular corrosion product was found on the metal surface. EDS analysis (Table 4) revealed the presence of iron, oxygen, and sulfur. Comparing Figure 7 with Figure 6, a less-intense sulfur peak is observed that can be ascribed to the decrease in $\mathrm{SO}_{2}$ content.

Figure 8 shows the surface morphologies of the two samples after cleaning with Clarke's solution. The polishing marks were still visible and localized attack was observed for both conditions, being more severe with $0.1 \% \mathrm{SO}_{2}$ than $0.05 \% \mathrm{SO}_{2}$. This suggests that localized corrosion could be accelerated by increasing $\mathrm{SO}_{2}$ concentration. Furthermore, it implies that even though uniform corrosion rate from the weight-loss measurement was low, localized corrosion can be initiated in the liquid $\mathrm{CO}_{2}$ phase with $\mathrm{SO}_{2}$.

Figures 9 and 10 present the results of IFM analysis of several pits observed on the cleaned sample exposed to the liquid $\mathrm{CO}_{2}$ for $24 \mathrm{~h}$, at a $\mathrm{CO}_{2}$ partial pressure of $8 \mathrm{MPa}, 25^{\circ} \mathrm{C}$. According to the depth of the deepest pits measured using IFM, the maximum localized corrosion rates were measured to be $6.8 \mathrm{~mm} / \mathrm{y}$ for the samples exposed to $0.1 \% \mathrm{SO}_{2}$ and $2.4 \mathrm{~mm} / \mathrm{y}$ for the samples exposed to $0.05 \% \mathrm{SO}_{2}$. Table 5 shows a comparison of the uniform and pitting corrosion rates observed under both experimental conditions. It is important to mention that the pitting corrosion rate

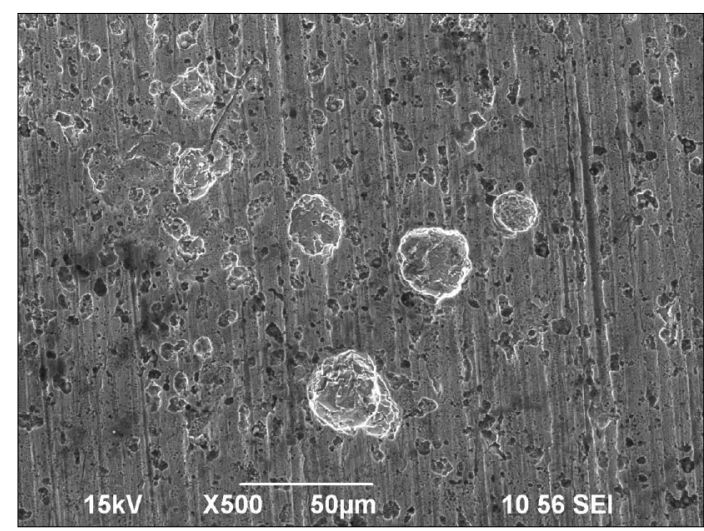

(a)

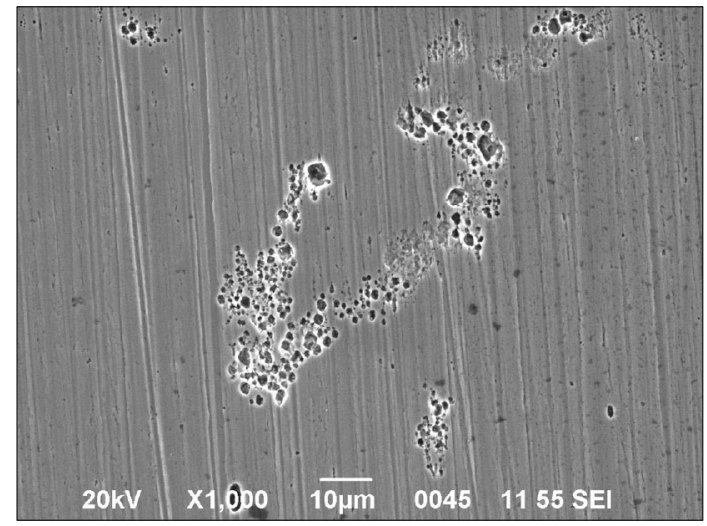

(b)

FIGURE 8. SEM images of the corroded surface of the samples exposed to the liquid $\mathrm{CO}_{2}$ for $24 \mathrm{~h}$, at a $\mathrm{CO}_{2}$ partial pressure of $8 \mathrm{MPa}, 25^{\circ} \mathrm{C}$, after cleaning: (a) $0.1 \% \mathrm{SO}_{2}$, (b) $0.05 \% \mathrm{SO}_{2}$.

of $6.8 \mathrm{~mm} / \mathrm{y}$ observed in liquid $\mathrm{CO}_{2}$ phase with $0.1 \%$ $\mathrm{SO}_{2}$ was even higher than the general corrosion rate reported by Choi and Nešici ${ }^{11}$ in supercritical $\mathrm{CO}_{2}$ with $1 \% \mathrm{SO}_{2}$ and $650 \mathrm{ppmv}$ of water.

Dugstad and Halseid ${ }^{17}$ suggested that the solubility of sulfurous/sulfuric acid $\left(\mathrm{H}_{2} \mathrm{SO}_{3} / \mathrm{H}_{2} \mathrm{SO}_{4}\right)$ formed when water and $\mathrm{SO}_{2}$ are present in the system seems to be low. This statement was confirmed in the present study by the presence of corrosion products formed in liquid $\mathrm{CO}_{2}$ phase when the water concentration (Figures 6 and 7) is below its solubility limit. Localized corrosion took place when acid droplets are deposited on the metal surface as it was observed by SEM and IFM analyses. However, no data has been found about the solubility limit of sulfurous/sulfuric acid in supercritical and liquid $\mathrm{CO}_{2}$ phases.

\section{CONCLUSIONS}

* Corrosion rates measured in liquid and supercritical $\mathrm{CO}_{2}$ with impurities like $\mathrm{H}_{2} \mathrm{O}$ and $\mathrm{SO}_{2}$ are still limited in the literature. This research contributes to CCS by showing experimental data that revealed potential corrosion problems during the transport of dense $\mathrm{CO}_{2}$ under such conditions. 


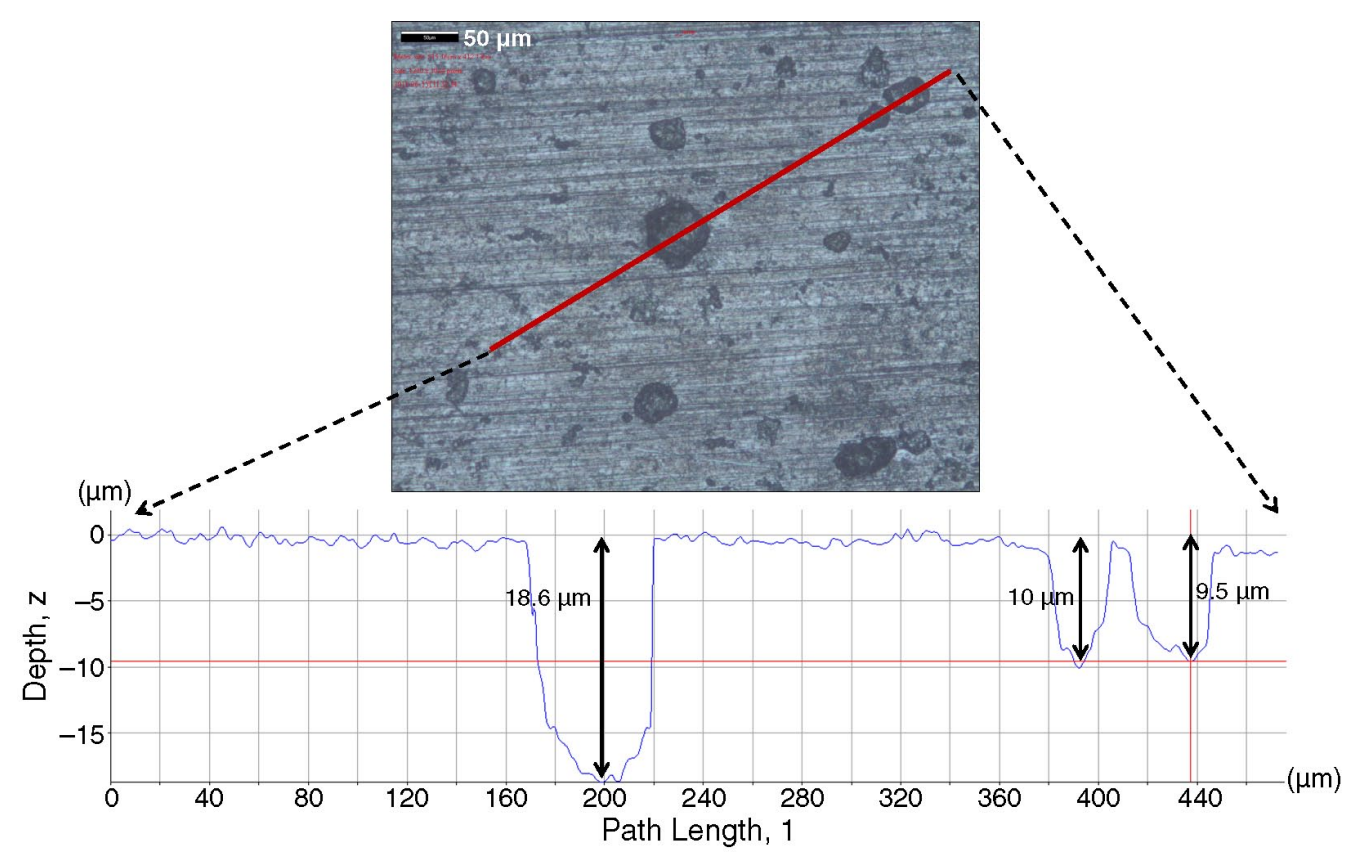

FIGURE 9. IFM analysis of the pits on the sample exposed to liquid $\mathrm{CO}_{2}$ with $0.1 \% \mathrm{SO}_{2}$ for $24 \mathrm{~h}$, at a $\mathrm{CO}_{2}$ partial pressure of $8 \mathrm{MPa}, 25^{\circ} \mathrm{C}$, after cleaning.

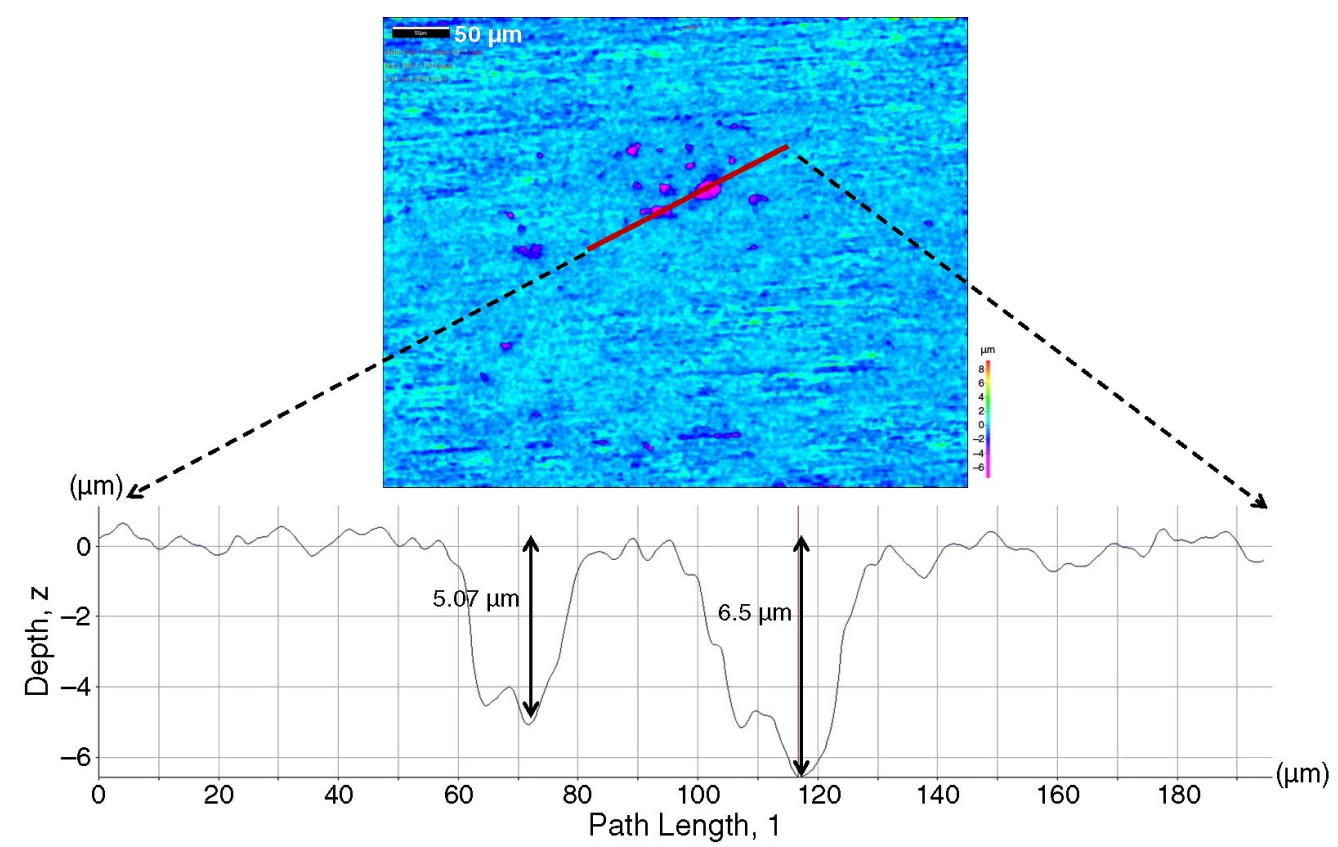

FIGURE 10. IFM analysis of the pits on the sample exposed to liquid $\mathrm{CO}_{2}$ with $0.05 \% \mathrm{SO}_{2}$ for $24 \mathrm{~h}$, at a $\mathrm{CO}_{2}$ partial pressure of $8 \mathrm{MPa}, 25^{\circ} \mathrm{C}$, after cleaning.

* In high-pressure supercritical $\mathrm{CO}_{2}$ systems containing $650 \mathrm{ppmv}$ water, the concentration of $\mathrm{SO}_{2}$ less than $0.1 \%$ did not lead to significant corrosion of carbon steel $(0.03 \mathrm{~mm} / \mathrm{y})$ in short-term experiments. * In the high-pressure liquid $\mathrm{CO}_{2}$ conditions with 650 ppmv of water, localized attack was seen with a rate of $6.8 \mathrm{~mm} / \mathrm{y}\left(0.1 \% \mathrm{SO}_{2}\right)$ and $2.4 \mathrm{~mm} / \mathrm{y}(0.05 \%$ $\mathrm{SO}_{2}$ ) in short-term experiments. These results showed that small amounts of $\mathrm{SO}_{2}$ are potentially harmful in liquid $\mathrm{CO}_{2}$ phase even in the presence of limited free water.

\section{ACKNOWLEDGMENTS}

The authors would like to thank the financial support from Ohio Coal Development Office (OCDO) 
TABLE 5

Comparison of Corrosion Rates Obtained from Weight-Loss Measurements and Infinite Focus Microscopy Analysis of Pit Penetration Depth for Samples Exposed to Liquid $\mathrm{CO}_{2}$ for $24 \mathrm{~h}$, at a $\mathrm{CO}_{2}$ Partial Pressure of $8 \mathrm{MPa}, 25^{\circ} \mathrm{C}$ and $50^{\circ} \mathrm{C}$, After Cleaning at Different $\mathrm{SO}_{2}$ Contents in the Liquid and Supercritical $\mathrm{CO}_{2}$ Phases

\begin{tabular}{|c|c|c|c|c|c|}
\hline $\mathrm{CO}_{2}$ Phase & $\begin{array}{c}\mathrm{SO}_{2} \\
\text { Content } \\
(\%)\end{array}$ & $\begin{array}{c}\text { Corrosion } \\
\text { Rate from } \\
\text { Weight Loss } \\
\text { (mm/y) }\end{array}$ & $\begin{array}{c}\text { Error } \\
(\mathrm{mm} / \mathrm{y})\end{array}$ & $\begin{array}{l}\text { Maximum } \\
\text { Pit Depth } \\
\text { from IFM } \\
\quad(\mu \mathrm{m})\end{array}$ & $\begin{array}{c}\text { Localized } \\
\text { Corrosion } \\
\text { Rate } \\
(\mathrm{mm} / \mathrm{y})\end{array}$ \\
\hline Liquid & 0.1 & 0.1 & 0.01 & 18.6 & 6.8 \\
\hline Liquid & 0.05 & $\approx 0$ & $\approx 0$ & 6.5 & 2.4 \\
\hline Supercritical & 1.0 & 3.5 & 0.21 & - & - \\
\hline Supercritical & 0.1 & 0.03 & 0.02 & - & - \\
\hline Supercritical & 0.05 & 0.05 & 0.01 & - & - \\
\hline
\end{tabular}

given to the Institute for Corrosion and Multiphase Technology at Ohio University.

\section{REFERENCES}

1. U.S. Environmental Protection Agency Report, "Inventory of U.S. Greenhouse Gas Emissions and Sinks: 1990-2009” (Washington, DC: U.S. Environmental Protection Agency, 2011), p. 7.

2. B.O. Metz, H. Davidson, C. de Coninck, M. Loos, L.A. Meyer, IPCC Special Report on Carbon Dioxide Capture and Storage, prepared by Working Group III of the Intergovernmental Panel on Climate Change (Cambridge, U.K., New York, NY, USA: Cambridge University Press, 2005).

3. Y. Xiang, Z. Wang, C. Xu, C. Zhou, Z. Li, W. Ni, J. Supercrit. Fluids 58 (2011): p. 286-294.

4. Z.X. Zhang, G.X. Wang, P. Massarotto, V. Rudolph, Energy Convers. Manage. 47 (2006): p. 702-715.

5. A. Mazzoldi, T. Hill, J.J. Colls, Int. J. Greenhouse Gas Control 5 (2011): p. 816-825.

6. J. Beck, S. Lvov, M. Fedkin, M. Ziomek-Moroz, G. Holcomb, J. Tylczak, D. Alman, "Electrochemical System to Study Corrosion of Metals in Supercritical $\mathrm{CO}_{2}$ Fluids," CORROSION/2011, paper no. 11380 (Houston, TX: NACE International, 2011).

7. Y. Zhang, K. Gao, G. Schmitt, "Water Effect on Steel Under Supercritical $\mathrm{CO}_{2}$ Conditions," CORROSION/2011, paper no. 11378 (Houston, TX: NACE, 2011).

8. E.M. Russick, G.A. Poulter, C.L.J. Adkins, N.R. Sorensen, J. Supercrit. Fluids 9 (1996): p. 43-50.

9. A. Dugstad, B. Morland, S. Clausen, Energy Procedia 4 (2011): p. 3063-3070.
10. Thodla, F. Ayello, N. Sridhar, "Materials Performance in Supercritical $\mathrm{CO}_{2}$ Environments," CORROSION/2009, paper no. 9255 (Houston, TX: NACE, 2009).

11. Y.S. Choi, S. Nešić, "Effect of Water Content on the Corrosion Behavior of Carbon Steel in Supercritical $\mathrm{CO}_{2}$ Phase with Impurities," CORROSION/2011, paper no. 11377 (Houston, TX: NACE, 2011).

12. D.P. Connell, "Carbon Dioxide Capture Options for Large Point Sources in the Midwestern United States: An Assessment of Candidate Technologies," Final Report, CONSOL Energy Inc., 2005, p. 7.

13. E.W. Lemmon, M.L. Huber, M.O. McLinden, "NIST Standard Reference Database 23: Reference Fluid Thermodynamic and Transport Properties-REFPROP," ver. 9.0 (Gaithersburg, MD: National Institute of Standards and Technology, Standard Reference Data Program, 2010).

14. P.N. Seevam, J.M. Race, M.J. Downie, P. Hopkins, "Transporting the Next Generation of $\mathrm{CO}_{2}$ for Carbon, Capture and Storage: The Impact of Impurities on Supercritical $\mathrm{CO}_{2}$ Pipelines," IPC200864063, 7th Int. Pipeline Conference (Calgary, Alberta, Canada: ASME, 2008).

15. ASTM G1-03, "Standard Practice for Preparing, Cleaning and Evaluating Corrosion Test Specimens" (West Conshohocken, PA: ASTM International, 2003).

16. J.F. Marco, J. Davalos, J.R. Gancendo, M. Gracia, Hyperfine Interact. 46, 1-4 (1989): p. 453.

17. A. Dugstad, M. Halseid, "Internal Corrosion in Dense Phase $\mathrm{CO}_{2}$ Transport Pipelines-State of the Art and the Need for Further R\&D," CORROSION/2012, paper no. C2012-0001452 (Houston, TX: NACE, 2012). 